\title{
Comparison between OPD-scan results and contrast sensitivity of three intraocular lenses: spheric AcrySof SN60AT, aspheric AcrySof SN60WF and multifocal AcrySof Restor lens
}

\author{
Estudo comparativo da análise de frente de onda \\ e sensibilidade ao contraste entre as lentes intra-oculares \\ multifocal AcrySof Restor SN60D3, monofocal AcrySof \\ SN60WF asférica e a monofocal SN60AT esférica
}

Celso Takashi Nakano', Wilson Takashi Hida', Newton Kara-Jose Junior ${ }^{3}$, Antonio Francisco Pimenta Motta', Danilo Fante², Victor Ferreira Masson², Alexandre Reis², Mauricio Pamplona², Iris de Souza Yamane',

Ricardo Holzchuh ${ }^{3}$, Amaryllis Avakian ${ }^{3}$

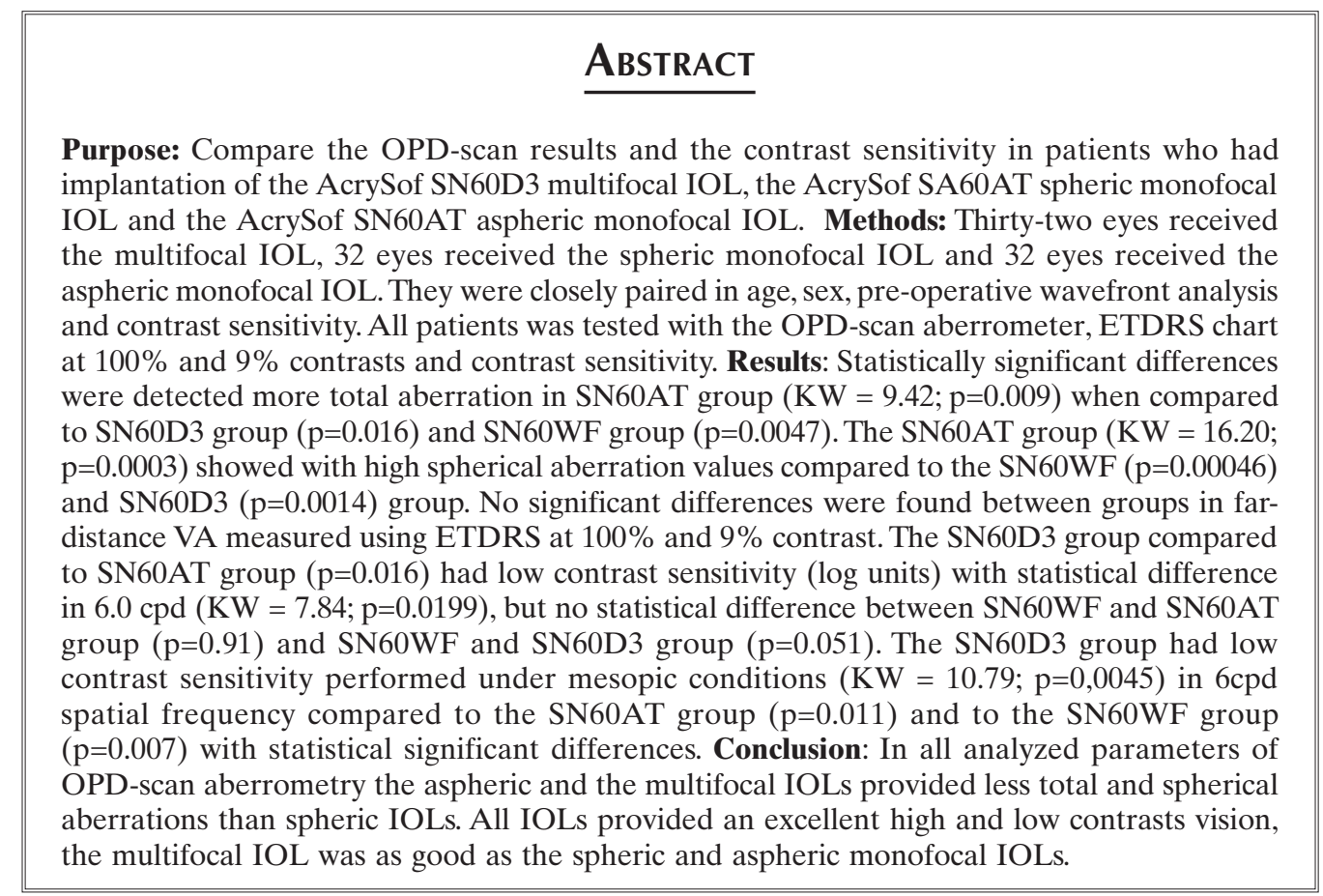

Keywords: Lenses; Lenses, intraocular; Contrast sensitivity; Phacoemulsification; Vision

\footnotetext{
${ }^{1}$ Estagiário do Setor de Catarata do Hospital das Clínicas da Universidade de São Paulo - USP - São Paulo (SP), Brasil;

${ }^{2}$ Residente do Hospital das Clínicas da Universidade de São Paulo - USP - São Paulo (SP), Brasil;

${ }^{3}$ Chefe do Setor de Catarata do Hospital das Clínicas da Faculdade de Medicina da Universidade de São Paulo - USP - São Paulo (SP), Brasil.
} 


\section{INTRODUCTION}

$\mathbf{W}$ avefront science has helped explain that this decline occurs because of increasing spherical aberration of the human lens ${ }^{(1-3)}$, New possibilities appeared when new technologies were developed, like the wavefront analysis using the Hartmann-Shack aberrometer and the optical path difference scan (OPD-scan), which measures the distance light travels in different paths going through the eye, measuring the optical system aberration ${ }^{(2,3)}$. The integration of wavefront technology and lens-based surgery represents a step toward improving functional vision and the quality of life for cataract patients ${ }^{(2-6)}$. As we have learned that the optical wavefront of the cornea remains stable throughout life, the lens has started to come into its own as a primary locus for refractive surgery ${ }^{(7)}$.

The evolution in cataract surgery has evolved with new surgical techniques, instrumentals, viscoelastic devices and IOL designs that provide high-quality optical imagery at all focal distance, since the first use of them by Ridley ${ }^{(1)}$. What remains is a challenge for optical scientists and material engineers to design a IOLs that compensate for any aberrations inherent in the cornea. The multifocal IOL try to minimize loss of incident light to higher orders of diffraction, reducing optical aberrations, and balancing the brightness of the focused and unfocused images ${ }^{(8)}$.

In the AcrySof ${ }^{\circledast}$ SN60D3 Restor ${ }^{\circledR}$ IOL, the logic of placing the diffractive element centrally depends on the near synkinesis of convergence, accommodation, and miosis. As the pupil constricts, the focal dominance of the lens shifts from almost purely distance to equal-parts' distance and near. This approach conserves efficiency for mesopic activities when the pupil is larger, such as night driving, but reduces near vision under mesopic conditions $^{(6)}$.

Contrast sensitivity testing has confirmed a decline in visual performance with age ${ }^{(6-10)}$. Improvements in ocular biometry and cataract surgery have minimized refractive error, promoting quick visual recovery, with low intraoperative complications, good postoperative quality of functional vision, more accurately described on the basis of the ability to precisely discern details of images regardless of lighting and brightness conditions $^{(7,11)}$

The purpose of this study is to compare the aberrometry results with OPD-scan and contrast sensitivity in patients who had implantation of the
AcrySof SN60D3 multifocal IOL, the AcrySof SA60AT spheric monofocal IOL and the AcrySof SA60AT aspheric monofocal IOL in cataract surgery.

\section{Methods}

This prospective, randomized study comprised 96 eyes of 48 patients selected between march 2005 and july 2006. This study was conducted according to established ethical standards for clinical research and the internal review board of our hospital approved the study protocol.

Inclusion criteria was age between 45 and 75 years old, presence of cataracts, classified by the Lens Opacity System II (LOCS II), and corneal astigmatism less than 1.00 diopter in both groups, with no other ocular pathologies, no previous ocular surgery or use of topic hipotensive medication and pupil diameter of at least 3.5 $\mathrm{mm}$ or more under mesopic and photopic light conditions as measured by the Colvard pupillometer (Oasis, Glendora). In addition, all patients with systemic disease potentially affecting vision or specifically affecting contrast sensitivity, such as diabetes retinopathy, were excluded. Patient with intraoperative or postoperative complications, including lens fixation that could not be classified as "secure and in-the-bag" or lens descentration greater than $0.5 \mathrm{~mm}$ were not included in the study.

A standard ophthalmic evaluation, performed in all visits, which included distance $(6 \mathrm{~m})$, intermediate $(70 \mathrm{~cm})$ and near $(33 \mathrm{~cm})$ best corrected and uncorrected visual acuity, biomicroscopy, intraocular pressure measurement and fundoscopy. The patients were randomized, using the Randomizer ${ }^{\circledR}$ program, into one of three groups for IOL implantation as follows: spheric monofocal group, AcrySof $^{\circledR}$ Natural $^{\circledR}$ (SN60AT, Alcon Labs), aspheric monofocal group, AcrySof ${ }^{\circledR} \mathrm{Natural}^{\circledR} \mathrm{WF}$ (SN60WF, Alcon Labs) and multifocal group, AcrySof ${ }^{\circledR}$ Restor $^{\circledR}$ (SA60D3, Alcon Labs).

All patients IOL calculation were done by immersion ultrasonic technique by single experienced examinator (A.F.P.M.) using the Ocuscan RXP biometer (Alcon Labs), and the IOL power selected with Hoffer$\mathrm{Q}$ or SRK/T formulas according to measured eye axial length ${ }^{(12)}$. Target refraction was plano (0D), or the first positive value for the multifocal group and target refraction was plano (0D), or the first negative value for the spheric and aspheric monofocal group.

Pupil diameters were Ginsburg box phtometer $\left(85 \mathrm{~cd} / \mathrm{m}^{2}\right.$ and $\left.6 \mathrm{~cd} / \mathrm{m}^{2}\right)$ by means of a Colvard pupillometer (Oasis, Glendora). All subjects underwent 
Table 1

Coma, spherical, high-order, and total aberrations in the SN60AT spheric, SN60WF aspheric and SN60D3 multifocal groups

\begin{tabular}{|c|c|c|c|c|c|c|}
\hline Variable & $\mathbf{N}$ & Median & SD & Min & Max & Kruskal-Wallis test \\
\hline TOTAL & & & & & & $\mathrm{KW}=9.42 ; \mathrm{p}=0.009$ \\
\hline SN60AT & 32 & 1.901 & 0.557 & 0.972 & 2.957 & SN60WF x SN60D3: $p=0.68$ \\
\hline SN60WF & 32 & 1.521 & 1.186 & 0.789 & 5.742 & S60WF x SN60AT: $p=0.0047$ \\
\hline SN60D3 & 32 & 1.284 & 0.535 & 0.730 & 2.495 & SN60D3 $x$ SN60AT: $p=0.016$ \\
\hline \multicolumn{7}{|l|}{ TILTS } \\
\hline SN60AT & 32 & 0.761 & 0.498 & 0.103 & 1.983 & $K W=0.64$ \\
\hline SN60WF & 32 & 0.793 & 0.808 & 0.218 & 3.734 & $p=0.73$ \\
\hline SN60D3 & 32 & 0.734 & 0.427 & 0.280 & 1.717 & \\
\hline \multicolumn{7}{|l|}{ HIGH } \\
\hline SN60AT & 32 & 0.878 & 0.206 & 0.519 & 1.161 & $K W=4.64$ \\
\hline SN60WF & 32 & 0.829 & 0.698 & 0.302 & 3.153 & $p=0.098$ \\
\hline SN60D3 & 32 & 0.752 & 0.322 & 0.292 & 1.523 & \\
\hline \multicolumn{7}{|l|}{ СОМА } \\
\hline SN60AT & 32 & 0.375 & 0.185 & 0.033 & 0.804 & $K W=1.04$ \\
\hline SN60WF & 32 & 0.426 & 0.474 & 0.170 & 2.137 & $p=0.59$ \\
\hline SN60D3 & 32 & 0.319 & 0.160 & 0.119 & 0.601 & \\
\hline \multicolumn{7}{|l|}{ TREFOIL } \\
\hline SN60AT & 32 & 0.499 & 0.261 & 0.191 & 0.953 & $K W=0.61$ \\
\hline SN60WF & 32 & 0.499 & 0.364 & 0.128 & 1.419 & $p=0.74$ \\
\hline SN60D3 & 32 & 0.519 & 0.334 & 0.118 & 1.311 & \\
\hline \multicolumn{7}{|l|}{ 4FOIL } \\
\hline SN60AT & 32 & 0.214 & 0.114 & 0.053 & 0.562 & $K W=0.94$ \\
\hline SN60WF & 32 & 0.217 & 0.195 & 0.043 & 0.730 & $p=0.62$ \\
\hline SN60D3 & 32 & 0.199 & 0.083 & 0.030 & 0.317 & \\
\hline SPHERICAL & & & & & & $K W=16.20 ; p=0.0003$ \\
\hline SN60AT & 32 & 0.422 & 0.202 & 0.007 & 0.618 & SN60WF x SN60D3 p=0.17 \\
\hline SN60WF & 32 & 0.124 & 0.087 & 0.019 & 0.353 & SN60WF $x$ SN60AT $p=0.00046$ \\
\hline SN60D3 & 32 & 0.174 & 0.132 & 0.019 & 0.515 & SN60D3 $x$ SN60AT $p=0.0014$ \\
\hline \multicolumn{7}{|l|}{ HiASTIG } \\
\hline SN60AT & 32 & 0.134 & 0.068 & 0.030 & 0.294 & $K W=1.08$ \\
\hline SN60WF & 32 & 0.214 & 0.346 & 0.040 & 1.478 & $p=0.58$ \\
\hline SN60D3 & 32 & 0.187 & 0.156 & 0.046 & 0.610 & \\
\hline \multicolumn{7}{|l|}{ RMS3 } \\
\hline SN60AT & 32 & 0.398 & 0.160 & 0.180 & 0.740 & $\mathbf{K W}=0.97$ \\
\hline SN60WF & 32 & 0.371 & 0.200 & 0.190 & 0.960 & $\mathrm{p}=0.62$ \\
\hline SN60D3 & 32 & 0.378 & 0.186 & 0.170 & 0.850 & \\
\hline \multicolumn{7}{|l|}{ RMS5 } \\
\hline SN60AT & 32 & 0.690 & 0.263 & 0.240 & 1.250 & $K W=3.14$ \\
\hline SN60WF & 32 & 0.564 & 0.283 & 0.320 & 1.410 & $\mathrm{p}=0.21$ \\
\hline SN60D3 & 32 & 0.647 & 0.414 & 0.310 & 1.750 & \\
\hline
\end{tabular}

wavefront analysis using the OPD-scan wavefront aberrometer (Nidek, Japan) under at least $6 \mathrm{~mm}$ dilated pupils with tropicamide $1 \%{ }^{(13-19)}$. Analysis of Wavefront Aberrations: One measurement by the OPD scan wavefront aberrometer from each eye was evaluated at 3 months postoperative day using software that follows the standards for calculating and reporting the optical aberrations of eyes. The parameters analyzed included 1) Root-mean-square (RMS) of HOA from the third to eighth orders; 2) RMS of the total spherical aberration;
3) RMS of total coma; and 4) RMS of total trefoil.

All performed monocularly with undilated pupils, uncorrected and with best correction in place. Visual acuity for far distance was tested with the Early Treatment Diabetic Retinopathy Study (ETDRS) chart $\mathrm{n}^{\mathrm{o}}$ 2106, Precision Vision, Aurora, Colorado, USA). at $100 \%$ and $9 \%$ contrasts, at a viewing distance of 4 meters under controlled photopic conditions ${ }^{(14)}$. In the multifocal group the spherical add power addition was zero diopters spheric and aspheric groups was 3,00 diopters. The 
Table 2

\begin{abstract}
Mean best corrected far visual acuity ETDRS chart with $100 \%$ and $9 \%$ contrast (logMar) between SN60AT spheric, SN60WF aspheric and SN60D3 multifocal groups
\end{abstract}

\begin{tabular}{lcccc}
\hline & SN60AT & SN60WF & SN60D3 & $\begin{array}{c}\text { Kruskal- } \\
\text { Wallis test }\end{array}$ \\
\hline ETDRS 100\% & & & & \\
· N & 32 & 32 & 32 & \\
- Average & -0.146 & -0.165 & -0.175 & \\
- SD & 0.125 & 0.128 & 0.123 & $\mathrm{KW}=1.61$ \\
- Median & -0.170 & -0.210 & -0.200 & $\mathrm{p}=0.45$ \\
- Minimum & -0.240 & -0.300 & -0.300 & \\
- Maximum & 0.280 & 0.100 & 0.080 & \\
ETDRS 9\% & & & & \\
- N & 32 & 32 & 32 & \\
- Average & 0.024 & -0.003 & 0.040 & \\
- SD & 0.056 & 0.176 & 0.169 & $\mathrm{KW}=0.14$ \\
- Median & 0.020 & 0.040 & 0.020 & $\mathrm{p}=0.93$ \\
- Minimum & -0.100 & -0.300 & -0.240 & \\
- Maximum & 0.140 & 0.220 & 0.420 & \\
\hline
\end{tabular}

luminance of the photopic translucent chart 4-meter test, and Jaegger chart intermediate distance test was established at $85 \mathrm{~cd} / \mathrm{m}^{2}$ (photopic) and for the near vision test a variation of $200 \mathrm{~cd} / \mathrm{m}^{2}$ was allowed.

Contrast sensitivity was measured by VCTS $® 6000$ (Vistech consultants) under photopic and mesopic conditions. The chart used displays sine-wave gratings at 5 standard spatial frequencies, from 1.5 to 18 cycles/ degree (cpd). The log (base 10) of the obtained values was then taken to obtain the contrast sensitivity values that were entered in the database for statistical analysis.

All surgeries were performed by the same senior surgeon (C.T.N.), with the same technique, described as follow: under topical anesthesia, a $2.75 \mathrm{~mm}$ self-sealing clear-cornea incision on the steepest meridian axis was created. After injection of cohesive and dispersive viscoelastic material (Celoftal and Provisc, Fortworth) with soft-shell technique, a continuous curvilinear capsulorhexis was created and hydrodisection were achieved with a solution of $1 \%$ non-preserved lidocaine in balanced salt solution ${ }^{(20)}$. Cataracts were extracted with Akahoshi prechop technique and by conventional phacoemulsification with Infiniti Vision System (Alcon Labs). After cortical aspiration, the IOL was placed in the bag with careful centration using Royale ${ }^{\circledR}$ (Asico) delivery system. In postoperative day 0 , patients were given topic fourth generation quinolones (gatifloxacin $0.1 \%$ ) four times a day for 7 days and steroids (dexametasone $0.1 \%$ ) four times a day decreased over 30 days. The patients were scheduled for postoperative clinical evaluation at day 1 , day 3, day 7 , day 30 and day 90 .

\section{Statistics}

Data were analyzed using the Statistical Program for Social Sciences (SPSS) version 10.0. and Statistica version 5.1/97. Statistical analysis of the results was performed by Kruskal-Wallis, Q-square and t student tests for analysis. Results were expressed as means \pm SD. A P value was adjusted less than 0.017 considered statistically significant.

\section{Results}

Of the 96 eyes included in the study, 32 were implanted with SN60WF, 32 with SN60AT and 32 with SN60D3 IOLs. No intra-operative complication was recorded in this study. There were no statistical difference between age, gender $(\mathrm{p}=0.92)$ and the operated eyes $(\mathrm{p}=0.37)$. The age was between 65.13 \pm 7.34 in SN60AT group, $66.43 \pm 8.45$ in SN60WF and $62.65 \pm 8.11$ years old in SN60D3 group ( $\mathrm{p}=0.45)$. The postoperative clinical course was uneventful in all groups.

The wavefront analysis (microns unit) is shown in Table 1. There were no significant differences in the mean root-mean-square (RMS) values of astigmatism aberration (HiAstig), tetrafoil (T4), trefoil (TT), total coma (TC), tilts (Ti) and higher-order aberration (HOA). The mean and standard deviation of total aberration (microns unit) values of SN60AT was $1.901 \pm 0.56$, SN60WF was $1.52 \pm 1.19$, and for SN60D3 group was 1.41 \pm 0.54 . Statistically significant differences were detected with more total aberration in SN60AT group $(\mathrm{KW}=9.42$; $\mathrm{p}=0.009)$ when compared to SN60D3 group $(\mathrm{p}=0.016)$ and SN60WF group $(\mathrm{p}=0.0047)$. No significant differences were found between SN60WF and SN60D3 groups $(\mathrm{p}=0.68)$. The SN60AT group $(\mathrm{KW}=16.20$; $\mathrm{p}=0.0003$ ) showed with high spherical aberration values compared to the SN60WF ( $\mathrm{p}=0.00046)$ and SN60D3 $(\mathrm{p}=0.0014)$ group. No statistical difference between SN60WF and SN60D3 group ( $\mathrm{p}=0.17)$.

The far-distance VA measured using ETDRS at $100 \%$ and $9 \%$ contrast are shown in table 2 . The SN60WF group was superior to other IOLs groups, and the differences were not statistically significant. $(\mathrm{p}=0.45$ in $100 \%$ and $\mathrm{p}=0.93$ in $9 \%$ ).

The results of contrast sensitivity under photopic conditions testing are given in figure 1. The SN60D3 group compared to SN60AT group $(\mathrm{p}=0.016)$ had low contrast sensitivity (log units) with statistical difference 


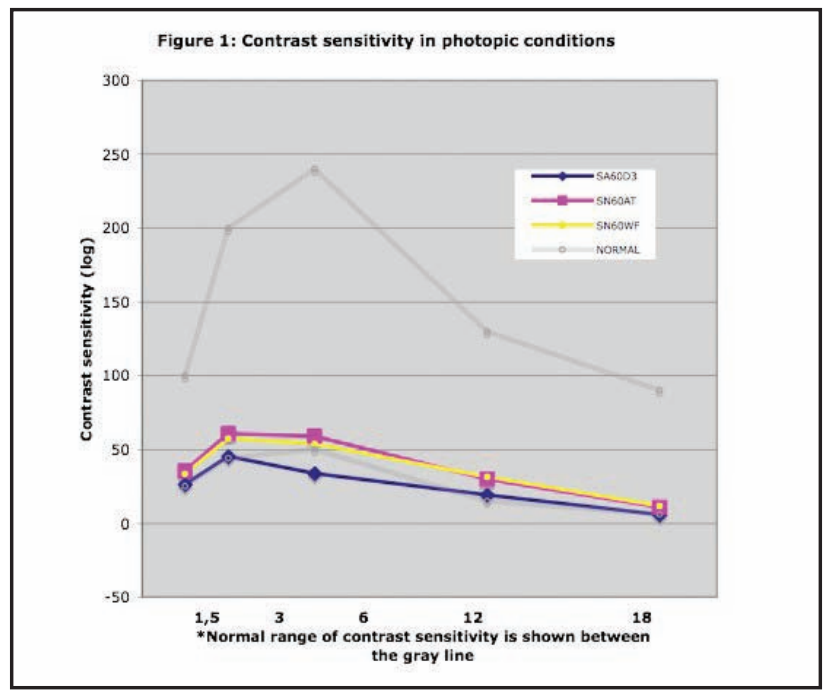

in $6.0 \mathrm{cpd}(\mathrm{KW}=7.84 ; \mathrm{p}=0.0199)$, but no statistical difference between SN60WF and SN60AT group $(\mathrm{p}=0.91)$ and SN60WF and SN60D3 group $(\mathrm{p}=0.051)$. No statistical difference was detected in $1.5 \mathrm{cpd}(\mathrm{KW}=$ 7.298; $\mathrm{p}=0.026), 3.0 \mathrm{cpd}(\mathrm{KW}=3.699 ; \mathrm{P}=0.16), 12 \mathrm{cpd}$ $(\mathrm{KW}=2.99 ; \mathrm{p}=0.22)$ and $18 \mathrm{cpd}(\mathrm{KW}=4.85 ; \mathrm{p}=0.089)$.

The results of contrast sensitivity under mesopic conditions testing are given in Figure 2. The SN60D3 group had low contrast sensitivity (log units) performed under mesopic conditions ( $\mathrm{KW}=10.79 ; \mathrm{p}=0.0045)$ in $6 \mathrm{cpd}$ spatial frequency compared to the SN60AT group $(\mathrm{p}=0.011)$ and to the SN60WF group $(\mathrm{p}=0.007)$ with statistical significant differences (Figure 2). No significant differences were detected comparison between SN60AT and SN60WF ( $\mathrm{p}=0.46$ ). No statistical difference was detected in $1.5 \mathrm{cpd}(\mathrm{KW}=0.66 ; \mathrm{p}=0.72)$, $3.0 \mathrm{cpd}(\mathrm{KW}=2.61 ; \mathrm{p}=0.27), 12 \mathrm{cpd}(\mathrm{KW}=3.35 ; \mathrm{p}=0.19)$ and $18 \mathrm{cpd}(\mathrm{KW}=1.54 ; \mathrm{p}=0.46)$.

\section{Discussion}

In this study, we investigated the OPD-scan analysis from the third to the eighth orders in a selected sample of 48 eyes, with a narrow range of refractive errors (range, -1.25 to 0.50 diopters) and a relatively wide age range (49 - 78 years). Studies investigated the correlation between ocular aberrations measured by wavefront technology and visual performance ${ }^{(15,18)}$. They found a high inverse correlation between aberrations and visual performance. This inverse correlation between ocular aberrations and visual performance was found only in data sets with a high range of aberrations and acuities ${ }^{16,18}$. Recently, studies found that higher-order aberrations, spherical aberration, and coma were weakly correlated

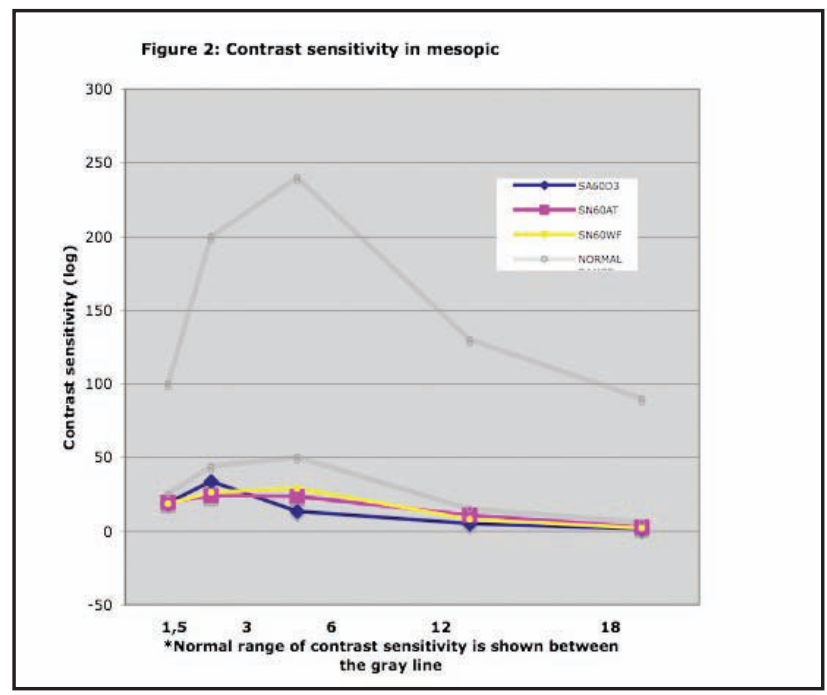

with age, and increasing age accounted for only $10 \%$ or less of the variation in these values ${ }^{(19,20)}$.

In regard to aberrations our study, we found more eyes with total and spherical aberrations in the SN60AT group as compared to SN60WF (total $\mathrm{p}=0.0047$; spherical $\mathrm{p}=0.00046$ ) and SN60D3 (total $\mathrm{p}=0.016$; spherical $\mathrm{p}=0.001$ ). There are no studies in the current literature that used the OPD-scan to compare visual performance in pseudophakic patients using multifocal or other IOLs. An experimental study showed significantly positive spherical aberration in eyes with spherical IOLs, compared to aspheric $\mathrm{IOL}^{(7)}$. Rocha and associates have the same results comparing multifocal with an aspheric $\mathrm{IOLS}^{(21)}$. There is no current published study comparing the OPD-scan aberrometry in aspheric IOLs with others, but Marcos and associates, showed in a experimental study significantly positive spherical aberration in eyes with spherical IOLs, compared with aspheric $\mathrm{IOLs}^{(7)}$.

Recent advances in aspheric monofocal lens design may lend themselves to improvements in multifocal IOLs as well. We now realize that the spherical aberration of a manufactured spherical IOL tends to increase total optical aberrations. Perhaps not all aberrations should be eliminated during cataract surgery because their deleterious effect is not clearly obvious and may probably vary according to their IOL type.

In our study the SN60AT, SN60WF and SN60D3 groups were implanted with blue-light filtering yellow tinted IOLs. This fact could interfere in the exams, but some authors have shown that there is no interference in the wavefront analysis, visual acuity, or in photopic or higher luminance mesopic contrast visual acuity with and without glare or chromatic discrimination using these IOLs ${ }^{(22)}$.

Associated with these IOL improvements, very 
precise axial length measurements provided to all patients an excellent uncorrected and best corrected final visual acuity at high contrast in ETDRS 100\% chart. The visual acuity in low contrast settings tested with ETDRS 9\% chart, all groups have an equal efficiency, but with a tendency to best performance in the WF group. There are no studies in the review of current literature published using this test to compare visual performance in pseudophakic patients using multifocal and other IOLs.

The monocular contrast sensitivity, at photopic conditions the SN60AT and SN60WF IOLs had gone better than SA60D3 without statistical significance, according with previous studies published, while others studies showed a statistically difference between the SA60AT and SA60D3 groups ${ }^{(10,23)}$. In mesopic conditions there were no statistical difference between the 3 groups. Other study showed lower contrast sensitivity under mesopic conditions in multifocal IOLs that used refractive technology ${ }^{(24)}$. Aberrations cause incoming light that would otherwise be focused to a point to be blurred, which in turn causes a reduction in visual quality. This reduction in quality is more severe under low luminance conditions because spherical aberration increases when the pupil size increases. More attention should be devoted to the relation between wavefront analysis and visual performance, and reassessment of their clinical significance is needed.

In conclusion, in all analyzed parameters of OPDscan aberrometry the aspheric and the multifocal IOLs provided less total and spherical aberrations than spheric IOLs. All IOLs provided an excellent high and low contrasts vision, the multifocal IOL was as good as the spheric and aspheric monofocal IOLs.

\section{Acknowledgements}

This study was presented previously in University of São Paulo Ophthalmology Congress in november 2006. There were no financial support or interest in the equipment or method mentioned, no research or traveling grant support, no consulting services provided, or commercial and proprietary interest.

\section{Resumo}

Objetivo: Comparar a sensibilidade ao contraste e análise de "wavefront" com OPD-scan em pacientes submetidos a cirurgia de facoemulsificação com implantes de lentes intraoculares AcrySof SN60D3 multifocal, AcrySof SN60WF monofocal asférica e AcrySof SA60AT monofocal esférica. Métodos: Trinta e dois olhos com a lente intraocular multifocal, 32 olhos com a lente intraocular monofocal asférica e 32 olhos com a lente intraocular monofocal esférica. A avaliação oftalmológica foi realizada no primeiro, terceiro, sétimo, e nonagésimo dia pós-operatório. Todos os exames foram padronizados, realizada por um único examinador sob condições controladas de luminosidade fotópicas estabelecidas em $85 \mathrm{~cd} /$ $m^{2}$, medida por meio de tabelas de ETDRS, sensibilidade ao contraste e análise de aberrometria com OPD-Scan. Resultados: As médias de aberração total foi superior no grupo $S N 60 A T(K W=9.42 ; p=0.009)$ quando comparada com o grupo $S N 60 D 3(p=0.016)$ e o grupo $S N 60 W F$ $(p=0.0047)$. O grupo SN60AT $(K W=16.20 ; p=0.0003)$ apresentou superioridade nas medias de aberração esférica comparada com o grupo SN60WF ( $p=0.00046$ ) e o grupo SN60D3 ( $p=0.0014)$. Nenhuma diferença significante foi encontrada na acuidade visual para longe com e sem correção óptica com a tabela de ETDRS a 100\% e 9\% de contraste. O grupo SN60D3 comparada a SN60AT $(p=0.016)$ apresentou baixa sensibilidade ao contraste em condições fotópicas com diferença estatística a $6.0 \mathrm{cpg}(\mathrm{KW}$ = 7.84; $p=0.0199$ ), mas sem diferença estatística entre os grupos SN60WF e SN60AT ( $p=0.91)$ e entre os grupos SN60WF e SN60D3 ( $p=0.051$ ). O grupo SN60D3 apresentou baixa sensibilidade ao contraste em condições mesópicas ( $K W=10.79 ; p=0,0045)$ a $6 c p g$ quando comparada com o grupos $S N 60 A T(p=0.011)$ e SN60WF ( $p=0.007)$. Conclusão: As lentes intraoculares multifocais e asféricas apresentaram menos aberração esférica quando comparadas à lente intraocular esférica, além da prevista multifocalidade sem correção para longe e perto. Entretanto, o grupo multifocal apresentou baixa sensibilidade ao contraste.

Descritores: Lentes; Lentes intraoculares; Sensibilidade de contraste; Facoemulsificação; Visão

\section{ReferenCeS}

1. Obuchowska I, Mariak Z. [Sir Harold Ridley—the creator of modern cataract surgery]. Klin Oczna. 2005;107(4-6):382-4. Polish.

2. Dietze HH, Cox MJ. Limitations of correcting spherical aberration with aspheric intraocular lenses. J Refract Surg. 2005;21(5):S541-6.

3. Guirao A, Redondo M, Geraghty E, Piers P, Norrby S, Artal P. Corneal optical aberrations and retinal image quality in patients in whom monofocal intraocular lenses were implanted. Arch Ophthalmol. 2002;120(9):1143-51.

4. Alió JL, Schimchak P, Negri HP, Montés-Micó R. Crystalline lens optical dysfunction through aging. Ophthalmology. 2005;112(11):2022-9. Comment in: Ophthalmology. 2007;114(3):618; author reply 619.

5. Rawer R, Stork W, Spraul CW, Lingenfelder C. Imaging quality of intraocular lenses. J Cataract Refract Surg. 2005;31(8):1618-31. 
6. Nio YK, Jansonius NM, Geraghty E, Norrby S, Kooijman AC. Effect of intraocular lens implantation on visual acuity, contrast sensitivity, and depth of focus. J Cataract Refract Surg. 2003;29(11):2073-81.

7. Marcos S, Barbero S, Jiménez-Alfaro I. Optical quality and depth-of-field of eyes implanted with spherical and aspheric intraocular lenses. J Refract Surg. 2005;21(3):223-35.

8. Friström B, Lundh BL. Colour contrast sensitivity with different intraocular lens materials in the right and left eyes in same day surgery. Acta Ophthalmol Scand. 2005;83(4):443-7.

9. Rodríguez-Galietero A, Montés-Micó R, Muñoz G, AlbarránDiego C. Comparison of contrast sensitivity and color discrimination after clear and yellow intraocular lens implantation. J Cataract Refract Surg. 2005;31(9):1736-40.

10. Oliveira F, Muccioli C, Silva LMP, Soriano ES, Souza CEB, Belfort Júnior R. Avaliação da sensibilidade ao contraste e da estereopsia em pacientes com lente intra-ocular multifocal. Arq Bras Oftalmol. 2005;68(4):439-43.

11. Bellucci R, Scialdone A, Buratto L, Morselli S, Chierego C, Criscuoli A, et al. Visual acuity and contrast sensitivity comparison between Tecnis and AcrySof SA60AT intraocular lenses: A multicenter randomized study. J Cataract Refract Surg. 2005;31(4):712-7. Erratum in: J Cataract Refract Surg. 2005;31(10):1857.

12. Olsen T, Nielsen PJ. Immersion versus contact technique in the measurement of axial length by ultrasound. Acta Ophthalmol (Copenh). 1989;67(1):101-2.

13. Auffarth GU, Holzer MP, Visessook N, Apple DJ, Völcker HE. Removal times for a dispersive and a cohesive ophthalmic viscosurgical device correlated with intraocular lens material. J Cataract Refract Surg. 2004;30(11):2410-4.

14. Vanden Bosch ME, Wall M. Visual acuity scored by the letterby-letter or probit methods has lower retest variability than the line assignment method. Eye. 1997;11(Pt 3):411-7.

15. Altmann GE. Wavefront-customized intraocular lenses. Curr Opin Ophthalmol. 2004;15(4):358-64.

16. Applegate RA, Hilmantel G, Howland HC, Tu EY, Starck T, Zayac EJ. Corneal first surface optical aberrations and visual performance. J Refract Surg. 2000;16(5):507-14.
17. Bellucci R, Morselli S, Pucci V. Spherical aberration and coma with an aspherical and a spherical intraocular lens in normal age-matched eyes. J Cataract Refract Surg. 2007;33(2):2039. Comment in: J Cataract Refract Surg. 2007;33(2):173-4.

18. Packer M, Fine IH, Hoffman RS, Piers P. Aberrations after intraocular lens implantation. J Cataract Refract Surg. 2006;32(2):184-5; author reply 185-6.

19. Bellucci R, Morselli S. Optimizing higher-order aberrations with intraocular lens technology. Curr Opin Ophthalmol. 2007;18(1):67-73.

20. Marcos S, Rosales P, Llorente L, Jiménez-Alfaro I. Change in corneal aberrations after cataract surgery with 2 types of aspherical intraocular lenses. J Cataract Refract Surg. 2007;33(2):217-26.

21. Rocha KM, Chalita MR, Souza CE, Soriano ES, Freitas LL, Muccioli C, Belfort R Jr. Postoperative wavefront analysis and contrast sensitivity of a multifocal apodized diffractive IOL (ReSTOR) and three monofocal IOLs. J Refract Surg. 2005;21(6):S808-12.

22. Mayer S, Wirbelauer C, Pham DT. [Functional results after intraocular lens implantation with or without blue light filter: an intraindividual comparison]. Klin Monatsbl Augenheilkd. 2006;223(2):142-6. German.

23. Souza CE, Muccioli C, Soriano ES, Chalita MR, Oliveira F, Freitas LL, et al. Visual performance of AcrySof ReSTOR apodized diffractive IOL: a prospective comparative trial. Am J Ophthalmol. 2006;141(5):827-32.

24. Alfonso JF, Fernández-Vega L, Baamonde MB, Montés-Micó R. Correlation of pupil size with visual acuity and contrast sensitivity after implantation of an apodized diffractive intraocular lens. J Cataract Refract Surg. 2007;33(3):430-8.

\section{Correspondig author: \\ Wilson Takashi Hida \\ Postal adress: Afonso de Freitas street, 488 - Paraíso CEP 04006-052 - São Paulo city - São Paulo state - Brazil}

